\section{Research Article}

Cite this article: Brunton DJ, Boutsalis $P$, Gill G, and Preston C (2018) Resistance to Multiple PRE Herbicides in a Field-evolved Rigid Ryegrass (Lolium rigidum) Population. Weed Sci 66:581-585. doi: 10.1017/wsc.2018.31

Received: 25 February 2018

Revised: 1 May 2018

Accepted: 6 May 2018

\section{Associate Editor:}

Vijay Nandula, United States Department of Agriculture

\section{Key words:}

Cross-resistance; herbicide resistance; multiple resistance; thiocarbamate herbicides.

\section{Author for correspondence:}

David Brunton, School of Agriculture Food and Wine, University of Adelaide, PBM 1, Glen Osmond, SA 5064, Australia. (Email: david. brunton@adelaide.edu.au)

\title{
Resistance to Multiple PRE Herbicides in a Field-evolved Rigid Ryegrass (Lolium rigidum) Population
}

David J. Brunton ${ }^{1}$, Peter Boutsalis ${ }^{2}$, Gurjeet Gill ${ }^{3}$ and Christopher Preston ${ }^{3}$

${ }^{1}$ Postgraduate Student, School of Agriculture Food and Wine, University of Adelaide, Glen Osmond, SA, Australia, ${ }^{2}$ Postdoctoral Fellow, School of Agriculture Food and Wine, University of Adelaide, Glen Osmond, SA, Australia and ${ }^{3}$ Associate Professor, School of Agriculture Food and Wine, University of Adelaide, Glen Osmond, SA, Australia

\section{Abstract}

A population of rigid ryegrass (Lolium rigidum Gaudin) from a field on the Eyre Peninsula, South Australia, was suspected of resistance to thiocarbamate herbicides. Dose-response studies were conducted on this population (EP162) and two susceptible populations (SLR4 and VLR1). The resistant population exhibited cross-resistance to triallate, prosulfocarb, EPTC, and thiobencarb with higher $\mathrm{LD}_{50}$ to triallate (14.9-fold), prosulfocarb (9.4-fold), EPTC (9.7-fold), and thiobencarb (13.6-fold) compared with the susceptible populations SLR4 and VLR1. The resistant population also displayed resistance to trifluralin, pyroxasulfone, and propyzamide. The $\mathrm{LD}_{50}$ of the resistant population was higher for trifluralin (13.8-fold), pyroxasulfone (8.1-fold), and propyzamide (2.7-fold) compared with the susceptible populations. This study documents the first case of field-evolved resistance to thiocarbamate herbicides in L. rigidum.

\section{Introduction}

The increase in herbicide-resistant weed species is a major threat to food production globally (Oerke 2006). Long-term use of herbicides as the primary form of weed control has selected for individuals capable of evading herbicide application (Gillespie 2010; Gressel 2009). Currently, 486 monocot and dicot weed species have evolved resistance globally to various herbicide sites of action (Heap 2017). Continued reliance on herbicides for weed control has resulted in new resistance cases reported in Australia and globally, including the evolution of metabolic resistance, which is of great concern, as it can confer unpredictable resistance to various sites of action, including herbicides never used (Beckie et al. 2013; Busi et al. 2013; Yu and Powles 2014).

Multiple weed species currently challenge Australian grain production systems (Llewellyn et al. 2016). The most problematic of these is rigid ryegrass (Lolium rigidum Gaudin), which is a genetically diverse, obligate-outcrossing weed species with widespread adaptations across all major cropping regions of southern Australia; it has evolved resistance to multiple herbicides with different sites of action (Busi et al. 2016; Han et al. 2016; Preston and Powles 2002; Yu and Powles 2014). The evolution of resistance in L. rigidum to selective POST acetyl-CoA carboxylase (ACCase)-inhibiting (diclofop-methyl) (Heap and Knight 1982) and acetolactate synthase (ALS)-inhibiting (chlorsulfuron) (Powles et al. 1990; Preston and Powles 2002) herbicides, including populations with multiple resistance (Preston et al. 1996), has shifted reliance to PRE herbicides from the thiocarbamate family. Increased reliance on thiocarbamate herbicides has ensued with the evolution of resistance to the PRE dinitroaniline herbicide trifluralin $\left(3^{(\mathrm{K} 1)}\right.$ : inhibitors of microtubule assembly). Trifluralin resistance is widely documented in southern Australia (Boutsalis et al. 2012; Broster and Pratley 2006). Release of the PRE herbicides prosulfocarb $\left(8^{(\mathrm{N})}\right.$ : inhibitor of fat synthesis) and pyroxasulfone $\left(15^{(\mathrm{K} 3)}\right.$ : inhibitors of very-long-chain fatty-acid synthesis) provided effective options for the control of L. rigidum in cereal and pulse crops (Boutsalis et al. 2014; Tanetani et al. 2013; Walsh et al. 2011). Thiocarbamate herbicides currently provide one of the two effective options for the control of $L$. rigidum in cereals. Resistance evolution to thiocarbamate herbicides threatens the sustainability of Australian grain production. Resistance to the thiocarbamates will reduce the effective control strategies in cereals, thereby restricting the control of L. rigidum to one herbicide (pyroxasulfone) (Walsh et al. 2011).

Only a few examples of weeds with resistance to thiocarbamate herbicides exist, one being triallate-resistant wild oat (Avena fatua L.) in Canada (Beckie et al. 2004, 2012; O'Donovan et al. 1994) with confirmed cross-resistance to pyroxasulfone and sulfentrazone (Mangin et al. 2016). Resistance to prosulfocarb has also been documented in blackgrass (Alopecurus 
myosuroides Huds.) populations across Denmark (Keshtkar et al. 2015). In addition, evolution of cross-resistance to prosulfocarb and triallate in L. rigidum was achieved by Busi and Powles (2013) in a glasshouse low-dose recurrently selected population MR4 displaying 58\% and 35\% survival, respectively. Busi and Powles (2016) also demonstrated cross-resistance to prosulfocarb $+S$-metolachlor and pyroxasulfone in L. rigidum recurrently selected with either herbicide.

Understanding the levels of resistance to thiocarbamate herbicides is necessary for the development of management strategies to slow the rate of resistance evolution and manage resistant weeds. The evolution of resistance to thiocarbamate herbicides has not yet been fully studied. The objective of this study was to determine the level of resistance and patterns of cross-resistance and multiple resistance in an L. rigidum population with suspected field-evolved resistance collected from Cockaleechie, Eyre Peninsula, South Australia, and to test its response to other PRE herbicides.

\section{Materials and Methods}

\section{Plant Material}

The seed of L. rigidum population EP162 (resistant [R]) used in this study was collected from a field in 2014 at Cockaleechie, Eyre Peninsula, South Australia $\left(34.21^{\circ} \mathrm{S}, 135.84^{\circ} \mathrm{E}\right)$ with a long history of crop production. Preliminary testing revealed resistance to multiple herbicide sites of action, including ACCase, ALS, microtubule assembly, fat synthesis, and 5-enolpyruvylshikimate3-phosphate inhibitors. Two well-characterized herbicide-susceptible L. rigidum populations, SLR4 and VLR1 (S), were also used in this study (Boutsalis et al. 2012).

\section{Seedling Growth and Herbicide Application}

Seeds from EP162, SLR4, and VLR1 were weighed $(0.2 \mathrm{~g}=50$ to 60 seeds) and spread onto the surface of $9.5 \mathrm{~cm}$ by $8.5 \mathrm{~cm}$ by $9.5 \mathrm{~cm}$ punnet pots (Masrac Plastics, SA, Australia) containing cocoa peat potting mix as described by Boutsalis et al. (2012). Herbicides were applied immediately using a laboratory spray cabinet equipped with flat-fan nozzles (Hardi ISO F-110-01, Hardi, Adelaide, SA, Australia) delivering $118 \mathrm{~L} \mathrm{ha}^{-1}$ water at a pressure of $4 \mathrm{kPa}$. Control pots were not treated with any herbicide. The experiment was conducted and repeated outdoors under natural growing conditions in winter during the normal growing season (July to August 2017). Pots were watered as needed to maintain potting mix near field capacity. There were three replicates for each herbicide dose, and pots were arranged in a randomized complete block design.

\section{Dose-Response Experiment}

Seven PRE herbicides were applied (Table 1) following the method described by Boutsalis et al. (2012). The PRE herbicide triallate was applied to $S$ biotypes at 25, 50, 100, 200, 400, 800, and $1,600 \mathrm{~g} \mathrm{ha}^{-1}$ and to the R biotype at 400, 800, 1,600, 3,200, 6,400, and $12,800 \mathrm{~g} \mathrm{ha}^{-1}$; in Australia, the recommended label rate of triallate for $L$. rigidum control is $1,500 \mathrm{~g} \mathrm{ha}^{-1}$. Prosulfocarb was applied to $\mathrm{S}$ biotypes at $37.5,75,150,300,600,1,200$, and $2,400 \mathrm{~g}$ $\mathrm{ha}^{-1}$ and to the $\mathrm{R}$ biotype at $600,1,200,2,400,4,800,9,600$, and $19,600 \mathrm{~g} \mathrm{ha}^{-1}$, with the recommended label rate for L. rigidum control being $2,400 \mathrm{~g} \mathrm{ha}^{-1}$. EPTC was applied to $\mathrm{S}$ biotypes at $67.5,135,270,540,1,080,2,160$, and $4,320 \mathrm{~g} \mathrm{ha}^{-1}$ and to the $\mathrm{R}$
Table 1. Active ingredients, formulations, and manufacturers of herbicides used in dose-response experiments.

\begin{tabular}{llcc}
\hline Active ingredient & Trade name & Formulation & Manufacturer \\
\hline Triallate & Avadex Xtra $^{\infty}$ & $500 \mathrm{~g} \mathrm{~L}^{-1}$ & $\begin{array}{c}\text { Nufarm Pty Ltd, } \\
\text { Australia }\end{array}$ \\
\hline Prosulfocarb & Arcade $^{\infty}$ & $800 \mathrm{~g} \mathrm{~L}^{-1}$ & $\begin{array}{c}\text { Syngenta Crop } \\
\text { Protection Pty } \\
\text { Ltd, Australia }\end{array}$ \\
\hline EPTC & Eptam $^{\infty}$ & $720 \mathrm{~g} \mathrm{~L}^{-1}$ & $\begin{array}{c}\text { Crop Care } \\
\text { Australasia Pty } \\
\text { Ltd, Australia }\end{array}$ \\
\hline Thiobencarb & Saturn & $800 \mathrm{~g} \mathrm{~L}^{-1}$ & $\begin{array}{c}\text { Bayer Crop Science } \\
\text { Pty Ltd, Australia }\end{array}$ \\
\hline Trifluralin & Trifluralin $^{\infty}$ & $480 \mathrm{~g} \mathrm{~L}^{-1}$ & $\begin{array}{c}\text { Imtrade Australia } \\
\text { Pty Ltd, Australia }\end{array}$ \\
\hline Propyzamide & Kerb $^{\oplus}$ & $500 \mathrm{~g} \mathrm{~L}^{-1}$ & $\begin{array}{c}\text { Dow AgroSciences } \\
\text { Pty Ltd, Australia }\end{array}$ \\
\hline Pyroxasulfone & Sakura & $850 \mathrm{~g} \mathrm{~kg}^{-1}$ & $\begin{array}{c}\text { Bayer Crop Science } \\
\text { Pty Ltd, Australia }\end{array}$ \\
\hline
\end{tabular}

biotype at 1,080,2,160,4,320,8,640, 17,280, and 34,560 $\mathrm{g} \mathrm{ha}^{-1}$, with the recommended label rate for $L$. rigidum control being $4,320 \mathrm{~g} \mathrm{ha}^{-1}$. Thiobencarb is not a registered herbicide for the control of L. rigidum in Australia but was included as another thiocarbamate herbicide and applied to $S$ biotypes at 56.25, 112.5, $225,450,900,1,800$, and $3,600 \mathrm{~g} \mathrm{ha}^{-1}$ and to the R biotype at 900, $1,800,3,600,7,200,14,400$, and $28,800 \mathrm{~g} \mathrm{ha}^{-1}$.

Additional PRE herbicides with different sites of action were included, as these provide an alternative option for the control of L. rigidum in Australia. Trifluralin was applied to $\mathrm{S}$ biotypes at $7.81,15.62,31.25,62.5,125,250$, and $500 \mathrm{~g} \mathrm{ha}^{-1}$ and to the $\mathrm{R}$ biotype at $125,250,500,1,000,2,000$, and $4,000 \mathrm{~g} \mathrm{ha}^{-1}$, with the recommended label rate for L. rigidum control being $500 \mathrm{~g} \mathrm{ha}^{-1}$. Propyzamide was applied to $\mathrm{S}$ biotypes at $7.81,15.62,31.25,62.5$, 125,250 , and $500 \mathrm{~g} \mathrm{ha}^{-1}$ and to the R biotype at 125, 250, 500, $1,000,2,000$, and $4,000 \mathrm{~g} \mathrm{ha}^{-1}$, with the recommended label rate for L. rigidum control being $500 \mathrm{~g} \mathrm{ha}^{-1}$. Pyroxasulfone was applied to $S$ biotypes at $1.6,3.2,6.4,12.8,25.5,51$, and $102 \mathrm{~g} \mathrm{ha}^{-1}$ and to the $\mathrm{R}$ biotype at $25.5,51,102,204,408$, and $816 \mathrm{~g} \mathrm{ha}^{-1}$, with the recommended label rate for $L$. rigidum control being $100 \mathrm{~g} \mathrm{ha}^{-1}$. Pots were assessed at $28 \mathrm{~d}$ after herbicide treatment, and plants that had emerged and grown to the 2-leaf stage were counted. Emergence was assessed as the number of plants germinating in the treated pots compared with the average number germinating in control pots and calculated as a percentage.

\section{Statistical Analysis}

Following an ANOVA, both experiment runs were pooled (no statistical difference between experimental runs) and analyzed using a log-logistic equation (GraphPad Prism v. 7.0, GraphPad Software, San Diego, CA) fit to the survival data. $\mathrm{LD}_{50}$ (dose required to reduce emergence by $50 \%$ of individuals in the population) parameter estimates from the log-logistic analysis were used to calculate the resistance index (RI), which is the resistant/susceptible ratio of the $\mathrm{LD}_{50}$. The model fit was

$$
y=\frac{100}{1+10^{\left(\log \mathrm{IC}_{50}-x\right) \times b}}
$$

where $y$ represents plant survival (\%) or biomass reduction (\%), $x$ is the log-dose of the herbicide used, $\mathrm{IC}_{50}$ is the herbicide dose 

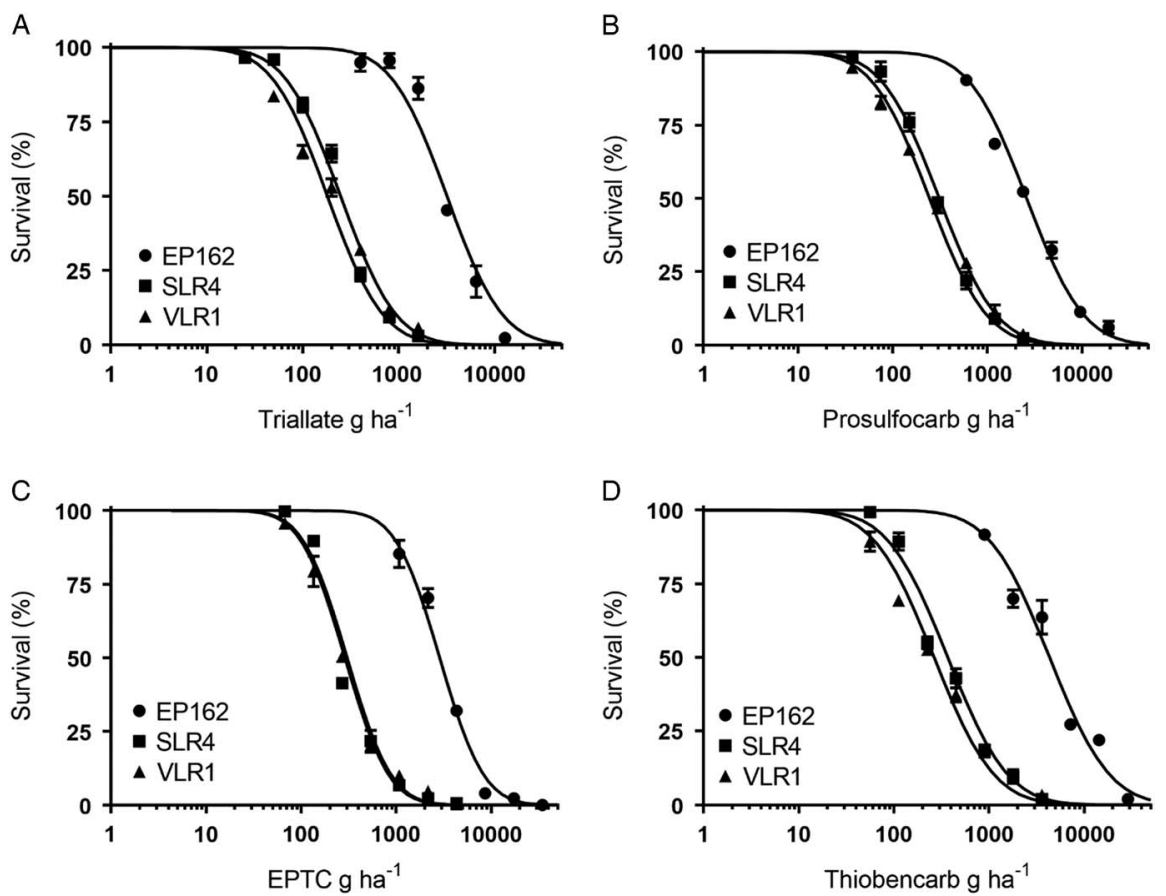

Figure 1. Response of EP162, SLR4, and VLR1 populations of Lolium rigidum treated with varying rates of triallate (A), prosulfocarb (B), EPTC (C), and thiobencarb (D). Each data point is the mean of six replicates, and bars represent standard error of the mean.

required to cause $50 \%$ reduction in plant emergence $\left(\mathrm{LD}_{50}\right)$, and $b$ denotes the slope of the curve.

\section{Results and Discussion}

Plants of the S populations SLR4 and VLR1 were completely controlled at $1,500 \mathrm{~g} \mathrm{ha}^{-1}$ triallate, the recommended field rate, while the resistant population EP162 showed no mortality at this rate (Figure $1 \mathrm{~A}$ ). The triallate rates required for $50 \%$ mortality $\left(\mathrm{LD}_{50}\right)$ for the SLR4 and VLR1 populations were $248 \mathrm{~g} \mathrm{ha}^{-1}$ and $181 \mathrm{~g} \mathrm{ha}^{-1}$, respectively (Table 2). The $\mathrm{LD}_{50}$ for the resistant population EP162 was 3,188 $\mathrm{g} \mathrm{ha}^{-1}$, giving an RI 14.9-fold higher than the mean of both $S$ populations. Prosulfocarb at the recommended rate of $2,400 \mathrm{~g} \mathrm{ha}^{-1}$ controlled both $\mathrm{S}$ populations, while EP162 had 48\% mortality at this rate (Figure $1 \mathrm{~B})$. The $\mathrm{LD}_{50}$ rates for SLR4 and VLR1 were $311 \mathrm{~g} \mathrm{ha}^{-1}$ and $246 \mathrm{~g} \mathrm{ha}^{-1}$, respectively, and 2,608 $\mathrm{g} \mathrm{ha}^{-1}$ for EP162 (9.4-hold higher than the $\mathrm{S}$ populations). EPTC completely controlled both $\mathrm{S}$ populations at the recommended rate of $4,320 \mathrm{~g} \mathrm{ha}^{-1}$, while the EP162 population showed $68 \%$ mortality at this rate (Figure $1 \mathrm{C}$ ). The $\mathrm{LD}_{50}$ rates for the SLR4 and VLR1 populations were $305 \mathrm{~g} \mathrm{ha}^{-1}$ and $288 \mathrm{~g} \mathrm{ha}^{-1}$, while the $\mathrm{LD}_{50}$ for the EP162 population was $2,867 \mathrm{~g}$ $\mathrm{ha}^{-1}$ (9.7-fold higher than the $\mathrm{S}$ populations). Even though thiobencarb is not registered for L. rigidum control in Australia, it completely controlled both $\mathrm{S}$ populations at $3,600 \mathrm{~g} \mathrm{ha}^{-1}$ (Figure 1D). The $\mathrm{LD}_{50}$ rates for thiobencarb for the SLR4 and VLR1 populations were $370 \mathrm{~g} \mathrm{ha}^{-1}$ and $265 \mathrm{~g} \mathrm{ha}^{-1}$, respectively, and 4,332 $\mathrm{g} \mathrm{ha}^{-1}$ for the EP162 population (13.6-fold higher than the $S$ populations).

Trifluralin completely controlled the SLR4 and VLR1 populations at the recommended rate of $500 \mathrm{~g} \mathrm{ha}^{-1}$, with the EP162 population recording $45 \%$ mortality at this rate (Figure $2 \mathrm{~A}$ ). The $\mathrm{LD}_{50}$ rates for SLR4 and VLR1 were $39 \mathrm{~g} \mathrm{ha}^{-1}$ and $27 \mathrm{~g} \mathrm{ha}^{-1}$, respectively, and $455 \mathrm{~g} \mathrm{ha}^{-1}$ for EP162 (13.8-fold higher than the $S$ populations) (Table 2). Propyzamide completely controlled both the $\mathrm{S}$ and $\mathrm{R}$ populations at the recommended rate of $500 \mathrm{~g}$ $\mathrm{ha}^{-1}$ (Figure $2 \mathrm{~B}$ ). The $\mathrm{LD}_{50}$ rates for the SLR4 and VLR1 populations were $30 \mathrm{~g} \mathrm{ha}^{-1}$ and $23 \mathrm{~g} \mathrm{ha}^{-1}$, respectively, and $74 \mathrm{~g} \mathrm{ha}^{-1}$ for the EP162 population (2.7-fold greater than the S populations). Pyroxasulfone completely controlled both $S$ populations at the recommended rate of $100 \mathrm{~g} \mathrm{ha}^{-1}$. The $\mathrm{LD}_{50}$ rates for the SLR4 and VLR1 populations were $9.5 \mathrm{~g} \mathrm{ha}^{-1}$ and $6.2 \mathrm{~g} \mathrm{ha}^{-1}$, respectively. The EP162 population displayed $28 \%$ survival to pyroxasulfone at the recommended rate (Figure $2 \mathrm{C}$ ) and an $\mathrm{LD}_{50}$ of $64 \mathrm{~g} \mathrm{ha}^{-1}$ (8.1-fold greater than the $\mathrm{S}$ populations).

The EP162 population of L. rigidum showed cross-resistance and a similar RI to the thiocarbamate herbicides triallate, prosulfocarb, EPTC, and thiobencarb (Table 2). This suggests a similar resistance mechanism may be providing resistance to the thiocarbamate herbicides in this population. Resistance to triallate

Table 2. Pooled dose-response data of triallate, prosulfocarb, EPTC, thiobencarb, trifluralin, propyzamide, and pyroxasulfone required for $50 \%$ mortality $\left(\mathrm{LD}_{50}\right)$ of resistant and susceptible Lolium rigidum populations with $95 \%$ confidence intervals (in parentheses) and resistance index (RI).

\begin{tabular}{|c|c|c|c|c|c|}
\hline Population & SLR4 & VLR1 & EP162 & $\mathrm{Rl}^{\mathrm{a}}$ & $P^{b}$ \\
\hline & \multicolumn{5}{|c|}{$-\mathrm{LD}_{50}$ in $\mathrm{g}$ ai ha ${ }^{-1}-$} \\
\hline Triallate & $248(201,308)$ & $181(151,217)$ & $3,188(2,347,4,347)$ & 14.9 & * \\
\hline Prosulfocarb & $311(259,375)$ & $246(209,289)$ & $2,608(2,012,3,374)$ & 9.4 & * \\
\hline EPTC & $305(238,390)$ & $288(231,357)$ & $2,867(2,005,4,070)$ & 9.7 & * \\
\hline Thiobencarb & $370(283,482)$ & $265(207,335)$ & $4,332(2,963,6,317)$ & 13.6 & * \\
\hline Trifluralin & $39(32,46)$ & $27(23,32)$ & $455(353,586)$ & 13.8 & * \\
\hline Propyzamide & $30(26,34)$ & $23(20,26)$ & $74(45,97)$ & 2.7 & * \\
\hline Pyroxasulfone & $9.5(7.6,11.3)$ & $6.2(5.1,7.6)$ & $64(46,88)$ & 8.1 & * \\
\hline
\end{tabular}

${ }^{\mathrm{a}} \mathrm{RI}$ as compared with the standard susceptible populations (SLR4 and VLR1).

${ }^{b}$ Probability value indicates significant differences in $L_{50}$ values between $L$. rigidum populations treated with a particular herbicide.

${ }^{\star} P<0.01$ 
A

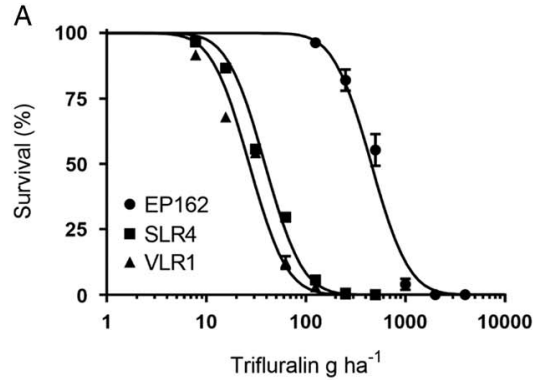

B

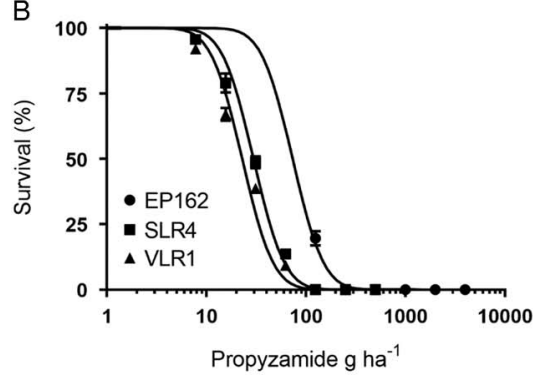

C

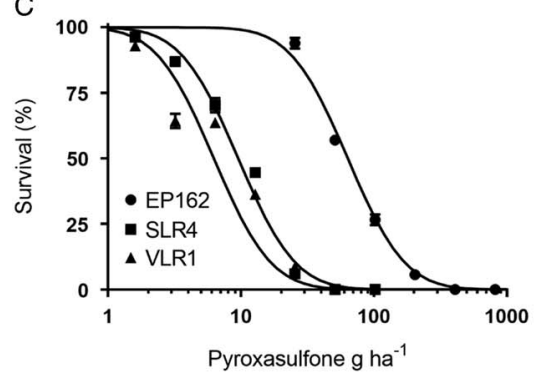

Figure 2. Response of EP162, SLR4, and VLR1 populations of Lolium rigidum treated with varying rates of trifluralin $(A)$, propyzamide $(B)$, and pyroxasulfone $(C)$. Each data point is the mean of six replicates, and bars represent standard error of the mean.

in A. fatua has previously been reported by Kern et al. (1996) to occur through reduced herbicide activation (sulfoxidation), and such a mechanism may provide cross-resistance to other thiocarbamate herbicides. However, reduced activation does not explain resistance in this population to other PRE herbicides, such as trifluralin, that do not require sulfoxidation for activation (Kern et al. 1996). The EP162 population shows a response profile more similar to an A. myosuroides population from Denmark as reported by Keshtkar et al. (2015), which has a non-target site resistance mechanism conferring strong resistance to the herbicides prosulfocarb and pendimethalin.

The level of resistance to prosulfocarb observed in this fieldselected population was similar to a recurrently selected $L$. rigidum population of Busi and Powles (2013). The RIs for triallate and thiobencarb were slightly higher than for prosulfocarb and EPTC, which could be related to the differences in water solubility and binding capacity among the thiocarbamate herbicides tested (Mangin et al. 2017; Westra et al. 2014). The EP162 population displayed a level of trifluralin resistance similar to a recent report of 17 -fold resistance conferred through a target-site point mutation in an L. rigidum population SLR74 (Fleet et al. 2017) and consistent with reported resistance in field-collected populations from across South Australia (Boutsalis et al. 2012). This observed level of resistance to other herbicide sites of action may be the result of enhanced herbicide metabolism via cytochrome $\mathrm{P} 450$ enzymes (Busi et al. 2017a) or by glutathione $S$-transferase conjugation with pyroxasulfone as reported by Busi et al. (2017b) in L. rigidum.

Dose-response experiments also identified resistance to pyroxasulfone. Despite this, pyroxasulfone still provided a considerable level of control (72\%) at the recommended field rate of $100 \mathrm{~g} \mathrm{ha}^{-1}$ (Figure 2C). In contrast, the resistance observed to propyzamide $\left(3^{(\mathrm{K} 1)}\right.$ : inhibitors of microtubule assembly) was much lower than pyroxasulfone. This herbicide still provided effective control of the population at the recommended rate. Even though propyzamide has the same site of action as trifluralin, propyzamide inhibits polymerization of tubulin into microtubules via a different mechanism compared with trifluralin as reported by Hoffman and Vaughn (1994). These differences in resistance can be explained by the repeated use of trifluralin leading to higher levels of resistance compared which propyzamide, which has been used primarily in canola (Brassica napus L.) after being registered in Australia in 2014. Variations in resistance within a site of action are known; different target-site mutations can result in different patterns of resistance to herbicides within a site of action (Preston 2017). In addition, herbicides belonging to the same site of action but to different chemical families will bind differently. One herbicide may be unable to bind, leading to resistance, while the binding of others may not be affected, leading to greater susceptibility (Oettmeier et al. 1991).

This study is the first documented case of field-evolved resistance to thiocarbamate herbicides in a population of $L$. rigidum. In response to widespread trifluralin resistance, use of the herbicide prosulfocarb has allowed growers to control L. rigidum in wheat (Triticum aestivum L.) and barley (Hordeum vulgare L.) in Australia. However, resistance evolution to thiocarbamate herbicides will result in increased reliance by growers on alternative herbicides such as pyroxasulfone and propyzamide. Potential resistance evolution to pyroxasulfone is of great concern, as this herbicide currently provides the most effective way of managing multiply resistant $L$. rigidum populations in wheat. The resistance to pyroxasulfone detected in the EP162 population suggests resistance to this herbicide could occur due to selection with trifluralin and/or prosulfocarb as reported by Busi and Powles (2016). Control of L. rigidum in canola is currently achieved with propyzamide $\left(3^{(\mathrm{K} 1)}\right)$; however, overreliance on propyzamide also increases the risk of resistance evolution to this herbicide. Evolution of cross-resistance and multiple resistance to PRE herbicides has made L. rigidum management increasingly difficult in Australian cropping systems. Australian growers will need to consider alternative strategies in addition to using propyzamide and pyroxasulfone to effectively manage $L$. rigidum in the future. These strategies will need to include mixtures of PRE herbicides, increasing crop competition with weeds, and the adoption of strategies to reduce weed seeds returning to fields (Beckie 2006; Walsh and Powles 2007).

Acknowledgments. The authors acknowledge the Grains Research and Development Corporation for funding this research and Alicia Merriam, Ruwan Lenorage, and GeethaVelappan for technical assistance with herbicide application and assessment. No conflicts of interest have been declared.

\section{References}

Beckie HJ (2006) Herbicide-resistant weeds: management tactics and practices. Weed Technol 20:793-814 
Beckie HJ, Hall LM, Meers S, Laslo JJ, Stevenson FC (2004) Management practices influencing herbicide resistance in wild oat. Weed Technol 18:853-859

Beckie HJ, Lozinski C, Shirriff S, Brenzil CA (2013) Herbicide-resistant weeds in the Canadian Prairies: 2007 to 2011. Weed Technol 27:171-183

Beckie HJ, Warwick SI, Sauder CA (2012) Basis for herbicide resistance in Canadian populations of wild oat (Avena fatua). Weed Sci 60:10-18

Boutsalis P, Gill GS, Preston C (2012) Incidence of herbicide resistance in rigid ryegrass (Lolium rigidum) across southeastern Australia. Weed Technol 26:391-398

Boutsalis P, Gill GS, Preston C (2014) Control of rigid ryegrass in Australian wheat production with pyroxasulfone. Weed Technol 28:332-339

Broster J, Pratley J (2006) A decade of monitoring herbicide resistance in Lolium rigidum in Australia. Anim Prod Sci 46:1151-1160

Busi R, Gaines TA, Powles S (2017a) Phorate can reverse P450 metabolismbased herbicide resistance in Lolium rigidum. Pest Manag Sci 73:410-417

Busi R, Girotto M, Powles SB (2016) Response to low-dose herbicide selection in self-pollinated Avena fatua. Pest Manag Sci 72:603-608

Busi R, Porri A, Gaines T, Powles S (2017b) Pyroxasulfone resistance in Lolium rigidum conferred by enhanced metabolic capacity. bioRxiv, 10.1101/116269

Busi R, Powles SB (2013) Cross-resistance to prosulfocarb and triallate in pyroxasulfone-resistant Lolium rigidum. Pest Manag Sci 69:1379-1384

Busi R, Powles SB (2016) Cross-resistance to prosulfocarb plus S-metolachlor and pyroxasulfone selected by either herbicide in Lolium rigidum. Pest Manag Sci 72:1664-1672

Busi R, Vila-Aiub MM, Beckie HJ, Gaines TA, Goggin DE, Kaundun SS, Lacoste M, Neve P, Nissen SJ, Norsworthy JK, Renton M, Shaner DL, Tranel PJ, Wright T, Yu Q, Powles SB (2013) Herbicide-resistant weeds: from research and knowledge to future needs. Evol Appl 6:1218-1221

Fleet B, Malone J, Preston C, Gill G (2017) Target-site point mutation conferring resistance to trifluralin in rigid ryegrass (Lolium rigidum). Weed Sci 66:246-253

Gillespie JH (2010) Population Genetics: A Concise Guide. 2nd ed. Baltimore, MD: John's Hopkins University Press. $232 \mathrm{p}$

Gressel J (2009) Evolving understanding of the evolution of herbicide resistance. Pest Manag Sci 65:1164-1173

Han H, Yu Q, Owen MJ, Cawthray GR, Powles SB (2016) Widespread occurrence of both metabolic and target-site herbicide resistance mechanisms in Lolium rigidum populations. Pest Manag Sci 72:255-263

Heap I (2017) The International Survey of Herbicide Resistant Weeds. www. weedscience.org. Accessed: September 15, 2017

Heap J, Knight R (1982) A population of ryegrass tolerant to the herbicide diclofop-methyl. J Aust Inst Agric Sci 48:156-157

Hoffman JC, Vaughn KC (1994) Mitotic disrupter herbicides act by a single mechanism but vary in efficacy. Protoplasma 179:16-25

Kern AJ, Peterson DM, Miller EK, Colliver CC, Dyer WE (1996) Triallate resistance in Avena fatua $\mathrm{L}$. is due to reduced herbicide activation. Pestic Biochem Physiol 56:163-173
Keshtkar E, Mathiassen SK, Moss SR, Kudsk P (2015) Resistance profile of herbicide-resistant Alopecurus myosuroides (black-grass) populations in Denmark. Crop Prot 69:83-89

Llewellyn R, Ronning DaC M, Mayfield A, Walker S, Ouzman J (2016) Impact of Weeds on Australian Grain Production-The Cost of Weeds to Australian Grain Growers and the Adoption of Weed Management and Tillage Practices. Canberra, Australia: Grains Research and Development Corporation

Mangin AR, Hall LM, Beckie HJ (2016) Triallate-resistant wild oat (Avena fatua L.): unexpected resistance to pyroxasulfone and sulfentrazone. Can J Plant Sci 97:20-25

Mangin AR, Hall LM, Schoenau JJ, Beckie HJ (2017) Influence of tillage on control of wild oat (Avena fatua) by the soil-applied herbicide pyroxasulfone. Weed Sci 65:266-274

O'Donovan JT, Sharma MP, Harker KN, Maurice D, Baig MN, Blackshaw RE (1994) Wild oat (Avena fatua) populations resistant to triallate are also resistant to difenzoquat. Weed Sci 42:195-199

Oerke EC (2006) Crop losses to pests. J Agric Sci 144:31-43

Oettmeier W, Hilp U, Draber W, Fedtke C, Schmidt RR (1991) Structureactivity relationships of triazinone herbicides on resistant weeds and resistant Chlamydomonas reinhardtii. Pestic Sci 33:399-409

Powles S, Holtum J, Matthews J, Liljegren D (1990) Herbicide Cross-resistance in Annual Ryegrass (Lolium rigidum Gaud). Washington, DC: ACS Publications

Preston C (2017) Recent advances in target site herbicide resistance mechanisms. Page 230 in Jugulam M ed., Biology, Physiology and Molecular Biology of Weeds. Boca Raton, FL: CRC

Preston C, Powles SB (2002) Mechanisms of Multiple Herbicide Resistance in Lolium rigidum. Washington, DC: ACS Publications

Preston C, Tardif FJ, Powles SB (1996) Multiple mechanisms and multiple herbicide resistance in Lolium rigidum. Pages 117-129 in Brown TM ed., Molecular Genetics and Evolution of Pesticide Resistance. Washington, DC: American Chemical Society

Tanetani Y, Ikeda M, Kaku K, Shimizu T, Matsumoto H (2013) Role of metabolism in the selectivity of a herbicide, pyroxasulfone, between wheat and rigid ryegrass seedlings. J Pestic Sci 38:152-156

Walsh MJ, Fowler TM, Crowe B, Ambe T, Powles SB (2011) The potential for pyroxasulfone to selectively control resistant and susceptible rigid ryegrass (Lolium rigidum) biotypes in Australian grain crop production systems. Weed Technol 25:30-37

Walsh MJ, Powles SB (2007) Management strategies for herbicide-resistant weed populations in Australian dryland crop production systems. Weed Technol 21:332-338

Westra EP, Shaner DL, Westra PH, Chapman* PL (2014) Dissipation and leaching of pyroxasulfone and S-metolachlor. Weed Technol 28:72-81

Yu Q, Powles S (2014) Metabolism-based herbicide resistance and crossresistance in crop weeds: a threat to herbicide sustainability and global crop production. Plant Physiol 166:1106-1118 